\title{
SAMHD1 Gene
}

National Cancer Institute

\section{Source}

National Cancer Institute. SAMHD1 Gene. NCI Thesaurus. Code C98203.

This gene is involved in both signal transduction and the immune response. 